\title{
Using Portfolio Assessment at Lower Secondary Education in Setswana Language Lessons
}

\author{
Eureka Mokibelo \\ University of Botswana, Botswana
}

\begin{abstract}
This study examined practices in academic progress record keeping at Junior Secondary Schools in Botswana in the Setswana language programme. Using the qualitative approach it was observed that students' academic progress at Junior Secondary Schools were recorded in scheme books with marks written at the back of it, either after an exercise or after writing monthly tests with no evidence produced when necessary during conferencing. The recordings did not show parents, educational officials and learners students' academic strengths and weaknesses in a particular skill they were supposed to develop in the teaching and learning processes. The study involved in-service teachers at Junior Secondary Schools who were furthering their education at the University of Botswana. A questionnaire with open ended questions and interviews were used to collect data from the participants. Data were analyzed using the grounded theory by considering thematic statements that emerged from key research questions. The findings indicated that the measures used for academic records by teachers were not systematic and effective. The study recommends portfolio assessment not as a means to an end, but as a strategy that can be adopted and used to develop a systematic way of keeping students' academic records and monitoring their academic growth and development progress.
\end{abstract}

Index Terms -Portfolio Assessment, Setswana Language, Teachers, Academic Records

\section{INTRODUCTION}

One of the major focus of language teaching is to motivate learners to a level where they can be independent, accountable and responsible for their learning. Therefore, teachers' expert knowledge on assessing language proficiency defines what language learners should know. Improvement and expansion of language teaching and learning at all levels is necessary. In this regard, the various stages of language proficiency are vital to what learners should achieve in the end. Portfolio assessment is one way of keeping learners' academic assessments and making them responsible and accountable for their work. "A portfolio is a collection of students' work done in a systematic way and it includes students various assessment, teacher observation and comments over a period of time.” (Cole, Ryan \& Kick, 2000). According to O'Malley \& Pierce (1996) the collection should adequately reflect students' development and progress in skills the course seeks to develop. Besides, Diamonds \& Moore, (1995) argue that the assessment or progress should relate to syllabus instructional goals. In addition to the latter, portfolios could be used to support to engage students, support good curricula and instruction, and improve student teaming. Again, some portfolios can be used to involve parents in their children's education programs and to report individual student progress. Sweet (1993) argues that portfolios should record successes; difficulties or ways of working that could otherwise be forgotten or ignored in the planning of instructions. Sweet (1993) expands on the successes by pointing out that portfolios could assist in improving future work, comparing achievements across classrooms, register types of work done and how much peers are engaged in revising drafts as well as deciding which piece of work is the best. All these could enhance learners' academic development. The definition of a portfolio demands that teachers should take an "extra mile" to record and keep safe the academic performance records of learners in a systematic manner that can be monitored.

Calfee \& Perfumo (1992) recognize the importance of a portfolio when they say that "the power of portfolio lies in helping teachers and students to focus on the teaching and learning processes." Further, the duo point out that a portfolio is essential because it systematically monitors students' progress in various skills in relation to the instructional goal. Again, Stahle \& Mitchell, (1993) emphasize that a portfolio fosters collaboration between teachers, students, administrators and education officials so as to put a concerted effort in developing students academically. Furthermore, it helps teachers and students to devise strategies to identify and remediate problematic areas. Both teachers and students are able to make reference to assignments, tests, and exercises in portfolios for reflection and information whenever questions arise regarding any learners' progress Wolf (1993). Last but not least, a portfolio creates a feeling of ownership since learners are responsible for their portfolios. Besides, learners are able to select and critique their writing. Most importantly, Flood \& Lapp (1989) contend that a portfolio contributes towards an effective means of communicating students' developmental status and progress in reading and writing to parents as is provides a wealth of information. From what the scholars say, we cannot undermine the crucial role a portfolio plays in a language classroom, especially where monitoring individual skills is concerned. Both the students and the teachers should be able to observe the development of basic language skills in a planned manner. 
Regarding the above, portfolio assessment is problematized in this context because since the shift from the structural to the communicative syllabus in Setswana at Junior Secondary School in 1997, it was not clear how the syllabus with two components of language and literature was supposed to be assessed, and how the marks or students' progress were supposed to be systematically recorded to monitor the development of basic language skills and literature component. It was observed that teachers used scheme books to keep learners academic progress in both language and literature components and this did not reflect which skill was tested and what marks they got. This procedure did not give teachers, school administrators, parents and other stakeholders any concrete language development and growth regarding students' academic progress in the Setswana subject. It was difficult for both parents and teachers to show and have evidence of how their learners are cognitively developing in both the language and literature components. Again, procedures did not make learners accountable and responsible for their work since there was no systematic way of keeping their continuous assessment records.

\section{BACKGROUND TO THE STUDY}

Setswana is a national language in Botswana. It is taught as a core subject at Junior Secondary Schools following the communicative language syllabus. The communicative language teaching syllabus for Setswana was introduced in 1997 at Junior Secondary Schools. The syllabus agitated for changes in roles of teachers and students, the way assessment was done, and academic records. The syllabus prescribed the teaching of basic language skills in the syllabus amongst other things. The implementation of the communicative language teaching (CLT) syllabus suggested that basic skills be tested accordingly. Setswana syllabus at junior secondary has defied odds by combining literature and grammar in one syllabus, but testing them separately even though the marks would combined at the final stage to make one grade. This practice has made the teaching of Setswana too demanding since one teacher teaches two disciplines simultaneously.

Despite the above, Setswana language and literature are tested through reading and writing skills. The listening and speaking skills are taught but not assessed during teaching and learning processes or even upon completion of the Setswana language programme after three years. (Junior Certificate Examinations Assessment Procedures- Setswana, 2000). Students are assessed through mid-year examinations, class exercises, monthly tests, written projects, and presentations. However, after marking continuous assessment, students are given their papers to keep without the teacher taking note of where they are kept. It has been observed that, many students shred or even throw away the papers if they have not performed well in a piece of assessment task. Some keep them in their personal files depending on whether or not they scored good marks. Parents, teachers and other educational professionals will not have access to those papers when there is need.

Although the syllabus tests reading and writing skills, record keeping of these basic language skills and the literature component lack clear guidelines and systematic recording. One would expect that students should be having basic language skills and literature component portfolios so that when parents come for conferencing at the end of each school term, they should be shown their children's weaknesses and strengths in the subject. Marks were recorded in scheme books without clearly stating what was being tested.

Scholars have raised a concern on the lack of smooth transition from the structural to the communicative syllabus, which has affected teaching and learning strategies that are related to the newly implemented ideas that are challenging in the communicative syllabus (Ramahobo 1999; Jankie 2001; Mokibelo 1999). From her study of 1999, Ramahobo (1999) quotes one of the interviewees as saying, 'I really see Setswana as a neglected language. (p .131)' This could be one reason why the notion of assessment has been also ignored in Setswana at Junior Secondary School level because Setswana has been "put in the shelves" for a long time. The best ways of assessing the language and literature components of Setswana and how such can be systematically monitored in the teaching and learning processes has not been addressed to date. Again Ramahobo (1999) notes that,

“...twelve years after the commission's work, there were no in-service training programmes in the communicative approach or in teaching language arts to handle the recommended syllabus. Hence, the results of lack of smooth transition are evident in that teachers' lessons are dominated by traditional approaches... p.148"

The above quote indicates a gap between training and implementation. It suggests that no systematic training has been provided for teachers to enable them to teach and test Setswana at Junior Secondary Schools.

The Junior Certificate (JC) principal examiners in their analysis of the examination highlight that students fail to demonstrate reading and writing skills in their scripts (Principal Examiners Reports, Examinations Research and Testing Division, 2002, 2003). This could be a consequence of the implementation that was left fluid. Cooter (1993) acknowledges that assessment is a way of testing students' knowledge and skills acquired after doing the course and it should be done systematically. In addition, Diamond \& Moore (1995) see assessment as a system that reveals students' communication competencies that are consistent with theories of teaching and learning. Such assessment would be meaningful if it is kept in portfolio for reference. Diamond \& Moore (1995) argue that when academic portfolios are kept, teachers and students are able to interpret, analyze, reflect and make decisions after noting the changes that need to be reflected on.

\section{Research Methodology}


The study adopted a qualitative approach, and it sought the views of in-service teachers on the use of portfolio assessment in their classes. The main purpose of this study was to accord students an opportunity to reflect on assessment procedures in their respective schools and check whether or not the assessments and recording system used were effective for both teachers, learners, parents, educational authorities and other stakeholders. The key research questions for this study were: a) what are your views about the current practice of keeping students' academic progress at junior secondary level after implementing the communicative syllabus in 1997?; b) what mechanisms are in place to keep students' academic records for reference?; c) what problems are encountered in using scheme books to record students' academic work?; d) how can the problems encountered above, if any, be addressed? These questions helped in interrogating and teasing out information on the problem under study.

The study was conducted in a period of three months at the University of Botswana in 2008. The study was conducted with a group of in-service teachers who were enrolled in a Bachelor of Education programme. These inservice teachers had been teaching for nine to twelve years and had also been transferred to various Junior Secondary Schools in various districts and were in a position to provide apposite information about assessment and recording of marks for Setswana. Besides, ten of them were already at the level of a senior teacher in the subject area, thus they had a broader perspective of what was happening in their departments, and schools. Again, some of them had been principal examiners for Junior Secondary Schools final examinations and had experiences of marking students' final examinations nationwide. Through their experiences a broader and richer view was given on portfolio assessment and academic record keeping. The group composed of 6 males and 14 female students, but the gender was of no impact to this study.

Therefore, convenience sampling was followed due to availability of respondents in the classroom. All the twenty inservice teachers came from nine different districts of Botswana and different Junior Secondary Schools and they were qualified teachers of Setswana. They had taught at the following area: Central District - Mahalapye, Serowe, Lerala, Bobonong, Letlhakane; North East - Francistown; Kgatleng:- Artersia, North West - Maun; Kweneng District Molepolole; Southern District -Jwaneng; South East District - Gaborone; Ghanzi District - Ganzhi; and Kgalagadi District - Tsabong. Most of the districts of Botswana were represented in this study. Important to note is that the Central District was represented by five Junior Secondary Schools that were far apart. The map below shows the main districts of Botswana.

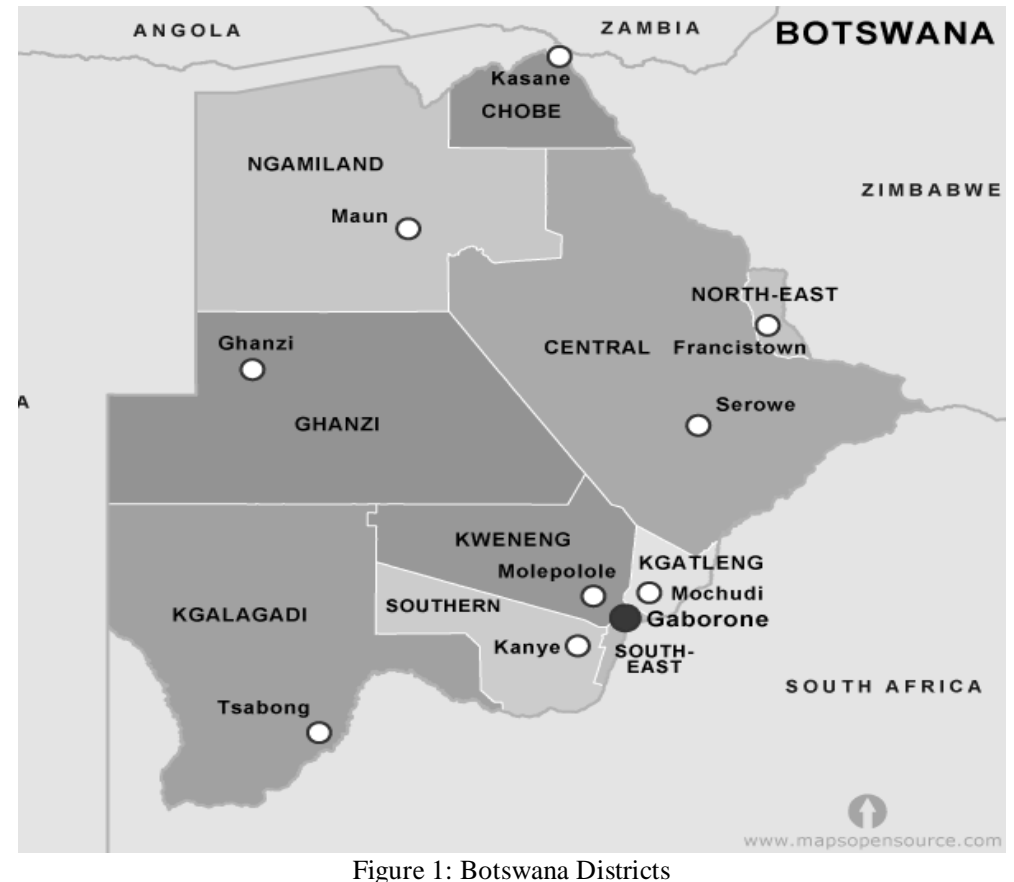

\section{Source: mapopensource.com}

The researcher used open ended questionnaires and she interviewed teachers on their understanding of continuous assessment and mid and end of year examinations record keeping in their various schools. The researcher opted for open ended questions because they were easy to administer. Also, they provided direct responses to factual and attitudinal questions. Participants were also interviewed to observe their reaction and responses to practices of continuous assessment record keeping regarding students' progress and their responses. Interviews were conducted to check the validity of open ended questions' responses. Also, the researcher used documents used by in-service teachers such as scheme books, report books and final examinations reports as evidence of what they used for recording their students' marks. The scheme books were important documents for this study because they were used by teachers for scheming, recording marks and reflecting on their teaching fortnightly. Also, scheme books recorded monthly academic 
progress of learners. Report books were also used to observe how examination marks were recorded and how teachers wrote comments for their learners' continuous assessment and mid-year and end of year examinations. The documents gave a broader view of how students' academic work was recorded.

Data were recorded and analyzed by each key research question to make sure that all the questions had been answered. Patterns and trends were observed in each key research question and they were noted. They were then categorized into thematic statements that were finally interpreted and analyzed.

The data and information in this study could not be generalized to other areas or schools because of its small representation of the teaching fraternity and the lack of representation of most of the Junior Secondary Schools in Botswana. The idea was to share information in the language field and reflect on some of the teachers' assessment procedures.

\section{CONCEPTUAL FRAMEWORK}

The study used various concepts borrowed from record keeping which started on medical grounds. Gibbs (1989) wrote an article on anesthesia records keeping which started as a way of assisting medical practitioners to successfully defend meritless claims made by patients and relatives. Therefore, he observed that failure to keep meaningful records, supportive or exculpatory documentation raises a lot of doubts and serious questions about the quality of care being rendered. Records, according to him assist in monitoring and data recording. In addition, according to Upward (1998) records keeping are vital because life is becoming more complex because of the changing social, technical and legal considerations. So it is important for people to have access to records and be able to communicate them reliably. Upward (1998) highlights that record keeping must provide historical evidence that provides insights into documents and transform what is being done; besides there must be continuity of medical records even if staff are transferred. Buckland (1994) argues that records management includes information retrieval, the life-cycle of the records and should be designed for workflow and protection of vital records. Therefore, the mission of records should be to service the needs, roles and activities of departments needing access to records.

The Department of Labour in the United States proposed rule of (2015) of Clarification of Employers Continuing Obligation to make and Maintain an Accurate Record of Each Recordable Injury or Illness. They point out that employers analyze and review the information in their records, and they can identify and correct problems and challenges in the workplace. The records are essential for employers to effectively manage their educational programmes, these records permit employers to track students' strengths and weaknesses over time so that they can evaluate the effectiveness of corrective measures implemented in response to identified problems and challenges. In this regard, teachers could become better informed about, and more alert to the challenges they are facing. Teachers who are aware of the challenges they face are likely to follow effective corrective and remedial measures and report them to educational authorities. The overall academic performance of learners and teaching approaches in the workplace is likely to improve. This process makes available the results for research purposes and for public information. Further decisions concerning improvement of learners' academic performance can continue to form the debates in educational circles.

The above concepts were used by the researcher to guide the use of portfolios in junior secondary schools. The concepts raise a number of issues that teachers and school administrations should take heed of. The notions challenge teachers to keep academic records of students for later referencing and further decision making. The concepts challenge teachers to use records that are communicating such that even if the staff member is transferred, those remaining can find the information useful and be able to use it. The concepts point towards the use of feedback and self-reflections as vital for further improvement and development. The perceptions compliment the idea that portfolios should be regarded as supportive evidence on the strength and weaknesses of students. In this regard, the concepts challenge teachers and school administration to be positive to move towards change, change that will benefit parents, learners, schools and other stakeholders. These thoughts give learners responsibility to look after their academic assessments records and to be accountable for it in the end. The notions give learners the opportunity to see their language development in each skill from one stage to another. The ideas encourage the teaching profession to collaborate and network with each other when portfolios are created to agree on what should go in the portfolios and how it should be managed. The concepts challenges educational authorities to change the structure of the scheme books and examination reports to better inform teachers, students, educational authorities and other stakeholders.

\section{THE RESUlts OF THE STUDY}

\section{Lack of understanding portfolio assessment}

Teachers reported that they did not use portfolio assessment in Setswana language classes and their reasons varied. Some teachers complained that they were not trained in better, and systematic ways of keeping students records. Others said that they thought the method was too expensive and could only be used in Private English Medium schools. Teachers appreciated the feedback involved with both parents and learners. Their comments were an indication that inservice training was inadequate to support the implementation of the communicative syllabus Ramahobo (1999); 
Mokibelo (1999) and Jankie (2001). Now that education and knowledge have changed, they needed to increase their knowledge to fit well with the ever-changing education systems.

\section{The Use of Scheme Books}

Most of the teachers reported that they recorded marks on last pages of their scheme books but very few said that they have personal notebooks where they kept students marks. They said: “...columns are provided at the back of the scheme books and so I use them..." "I keep my students' marks in a personal notebook if scheme books are not yet available..." The teachers' comments unravelled that they were still adopting the traditional way of recording students' academic progress where numbers are supposed to communicate to the reader. Below is a sample from one of the teachers on how the back of the scheme book looked like and the recording of marks was done. Names of students in the "names of pupils" column are not real.

TABLE 1:

SAMPLE OF MARKS RECORDED IN TEACHERS' SCHEME BOOK AT JUNIOR LEVEL

\begin{tabular}{|l|l|l|l|l|l|l|l|l|l|l|l|}
\hline Names of pupils & Jan & Feb & March & April & May & June & July & Aug & Sept & Oct & Nov \\
\hline Thabang & 40 & 30 & 60 & 20 & 50 & 55 & 66 & 70 & 40 & 30 & 60 \\
\hline Mpho & 70 & 40 & 57 & 10 & 70 & 60 & 55 & 68 & 50 & 60 \\
\hline Tlotlo & 30 & 60 & 58 & 25 & 50 & 48 & 55 & 66 & 30 & 60 & 63 \\
\hline Leatile & 55 & 56 & 40 & 30 & 40 & 68 & 45 & 70 & 50 & 65 & 66 \\
\hline Gontle & 64 & 45 & 58 & 20 & 50 & 60 & 58 & 70 & 60 & 45 & 62 \\
\hline
\end{tabular}

The above marks do not communicate much to learners, parents, educational authorities and teachers in terms of basic language skills' development and growth without teachers' comments and the students' reflections. The marks do not indicate the students' strengths and weaknesses. Again, it is not clear which basic language skill has been tested. Hughes (1989) observed that, “ Too often language tests have a harmful effect on teaching and learning; and too often they fail to measure accurately whatever it is they are intended to measure. (p.1)" Records such as the one above could be harmful to both the learner and the teacher, since they are 'silent' on what takes place during teaching and learning and even testing.

According to in-service teachers' reports, after mid-year examinations, marks were recorded in the report book with short phrasal comments next to the mark due to the small space provided for such comments. Comments such as the ones below dominated the remarks column in teachers old report books: 'pull up your socks'; 'not serious;' 'average;' 'excellent;' 'poor performance;' 'more effort needed;' 'work hard;' 'too playful;' 'noisy;' 'always late' and 'disobedient'. One could ask whether the above comments could assist learners to improve their performances in a particular language skill or communicate to parents and educational authorities.

\section{Lack of Comments and Reflections}

All teachers admitted that they did not record marks with comments and said marks recorded with comments were found in report books that recorded students' performances in the mid-year and end of year examinations only. Most teachers reported that their scheme books had no space for comments. The document had been designed as such and that even though they used personal scheme note books it could be illegal document. Duke and Sanchez (2000) accentuate the benefits of using portfolio assessment as providing opportunities for students' performance on a variety of tasks and also revealing students work process. Further, the duo see portfolios as involving students in using high order thinking skills appropriate for work place and also offering a convenient method for documenting their progress. Most importantly Duke and Sanchez (2000) claim that portfolios offer students an opportunity to assess their own performance. It is in the light of this argument that scholars are now questioning the way academic progress record keeping of learners is carried out. Jones \& Bray (1986) argue that assessment has to go along with comments, selfreflections, and teacher observations.

\section{Testing of Basic Language Skills not Systematically Recorded}

All teachers reported that they did not indicate which language skill has been tested because they just chose areas they wanted to randomly. Teachers reported that literature had poetry and texts, and the language component had a variety of writing genres such as reading comprehension, composition, summary writing, letter writing and so forth. These were however not recorded as such in their schemes, only marks were recorded.

There is an indication that teachers were not even aware that they were developing skills. They did not concentrate on developing and testing basic language skills. They just taught topics in classes and ignored instructional goals.

\section{Keeping of Students Assessment Papers}

All teachers reported that students were given their test and examination papers to keep at home. These were not used as references at any point, let alone during teachers and parents conferencing. Most teachers reported that it was the responsibility of learners to keep their assessment papers but they did not expect them to bring their papers during conferencing. Teachers also reported that there were storerooms in their classes, but they could not keep students work in them because storerooms have a lot of books and some kept cleaning materials for their classrooms. After every assessment, be it a test, examination or presentation of papers, students were given their papers to show their parents and there was no evidence that indeed the papers reached the parents. Some of them, especially for those who had performed badly, ended up in rubbish bins. There were very few students who kept their work in files for future 
references not because teachers or parents might need them, but just because the students decided to keep their own papers.

\section{Conferencing with parents}

Teachers reported that they used marks in the scheme books and the report books to discuss students' progress with teachers. Most of them reported that since they taught students, they were aware of their behaviours, which they could report to parents during conferencing. Almost all of them reported that low marks indicated that the student did not do well and the high marks indicated that the students did quite well. Teachers reported that they used marks in report books and scheme books during meetings and conferencing. Teachers' comments indicated that numerics were enough to convey messages about the performances of students. However, when it came to conferencing, most teachers concentrated on the behaviours of students and would say very little about the academic progression of students. After all, parents had to move about to see eight to nine teachers, so they also preferred to spend very little time with one subject teacher. In the end very little information would have been passed on about students' progress in different skills.

\section{Accessing Students Recorded marks}

Teachers indicated that scheme books were for teachers and not students and parents. However, some said when necessary parents would be shown the marks if they wanted to see the progress of their children. Teachers reported that scheme books were checked by senior teachers for the subject to see if they were scheming, and teaching topics that appeared in the syllabus. But parents had no access to scheme books. The responses from teachers meant that scheme books were only accessible to teachers and administrators" Perhaps we should have a closer look at the goals of multicultural education, which spells out that parents and other stakeholders should be empowered to be responsible for their children's education. Going by this principle, one can argue that denying parents access to information about their children's academic progress discriminated them.

\section{Effectiveness of the current assessment}

Most teachers observed that the system was not working in their favour hence most candidates did not perform up to standards in the final examinations but could not suggest what could work best for them. Teachers confirmed that scheme books were official documents from the Ministry of Education and Skills Development and therefore they had to use them. In this regard, it was the responsibility of the Ministry of Education to review documents used for assessment and it meant that if they did not complain about them, then they were okay. All of them identified the discrepancies and inadequacies in the schemes they used for recording learners' marks. In one voice teachers reported that portfolio assessment could be an effective strategy for assessing their students. These comments showed some concern from teachers that somehow the Setswana subject was neglected; they felt there must be changes done to focus what they are doing at the moment. It is important to note that some teachers at junior secondary level found keeping students' assessment too demanding, again as they put it, they did not teach in permanent classrooms where they could keep portfolios for students. Teachers' comments indicated that teachers never used to critique the system; nobody had ever questioned the validity and reliability of it because, they were stuck on the traditional way of doing things. Most of them were comfortable with what they were doing probably because they did not know anything about portfolio assessment.

\section{DISCUSSION OF FINDINGS}

\section{Portfolio assessment a far-fetched phenomenon}

The results from the study revealed a common pattern that portfolio assessment in Setswana language was not understood by teachers of Setswana and yet it could assist in focusing and planning systematically the teaching and learning processes of Setswana language. It was a far-fetched phenomenon. Keeping the records in students' portfolios could help teachers to reflect on their work and promote improved teaching (Calfee \& Perfumo, 1992). Teachers needed to set realistic goals for portfolio assessment and this could have increased the probability of sustained teacher interest and use. Marks recorded at the back of a scheme book showed snap shots of students' ability in various discourses of language and literature teaching and learning. Teachers agreed that marks did not indicate whether the test was on summary, composition, poetry or a literature text. As such, it was difficult to make solid decisions on teacher pedagogy, teaching materials and instructional approaches used in the language and literature classes and the curriculum to improve students learning (Jones \& Bray, 1992).

\section{Inadequately designed scheme books}

The system of having marks recorded at the back of a scheme book did not reflect any shared vision regarding students' academic work. It was evident from the study that scheme books used were inadequately designed. They did not have any space where teachers could note their comments even if they had wished to. Portfolio assessment would show the processes of students' growth and active learning and therefore it should contain multiple sources of students' language activities. According to Valencia (1990) marks that were not accompanied by students' reflections, written summaries or teachers' comments could not give a true reflection, true depth and breadth of students' abilities in many domains of learning. As such teachers would not get constant feedback on students' performance and learning objectives Hughes (1989). O’Malley \& Pierce (1996) suggested that portfolios should adequately reflect students' development and progress in basic language skills developed. Calfee \& Perfumo (1992) summarize the shared vision by 
saying that the power of a portfolio lies in helping teachers and students focus on teaching and learning processes and also for monitoring progress of students (see also Stahle \& Mitchell, 1993).

\section{Traditional pedagogical practices}

Portfolio assessment demanded a shift in pedagogical practices that could be seen as developing student-centred learning and communicative competence in whole language and literature teaching. As Valencia (1990) argues, marks that are unaccompanied by constructive comments from teachers, do not advocate for where teachers could focus regarding the strengths and weaknesses of learners, leaving the assessment procedures fluid. Importantly, pedagogical practices in the communicative syllabus demanded that teachers could tailor portfolio assessment procedures to the purpose for which it was used, to lesson goals and objectives and to individual student assessment needs. Therefore, assessment instruments and procedures could be adapted to match and reflect student characteristics, and to coincide with student linguistic and developmental capabilities (Moya \& O'Malley, 1994).

The assessment procedures and documents did not represent informative ways of illustrating and evaluating students' work to educational authorities, visitors and parents. Wolf, (1993) argues that parents, visitors and educational professionals were supposed to have access to students' portfolios as important stakeholders. In this regard, there was supposed to be transparency so that when decisions were made about curriculum instruction, they would be made on concrete evidence on the performance of students by all stakeholders involved.

\section{Implications}

Measures used for recording students' academic progress had implications for teacher pedagogy and classroom teaching. Students' academic records were unsystematically recorded and kept. It was not clear which skills were tested and which genre of literature was tested and what feedback was given. Low or high marks recorded alone were not adequate enough to paint a true picture of students' capabilities.

The system that was used put teachers in difficult positions to reflect and improve their teaching and learning. Teachers were unable to critically assess and analyze their teaching pedagogy, hence conferencing could be based on social discipline rather than on academic improvement.

The system was discriminatory as it left out parents, visitors and educational authorities. As shown above, these important stakeholders did not have access to teachers' scheme books because it was an official document which could be accessible to teachers only.

\section{Conclusion}

Systematic procedures of recording marks and keeping students work for conferencing with students, parents and educational authorities is jeopardized by the use of scheme books. As such a change of mindset is necessary and rigorous training of academic record keeping could be a solution to an informative way of recording students' progress marks. It is important to have evidence of students' progression. Teachers must have concrete evidence to conference with students, parents and educational authorities, and they must have tangible evidence to support themselves when they discuss academic issues with parents and educational authorities. If teachers of Setswana from junior secondary schools can continue recording students' progress the way it is done, then we cannot talk about quality teaching and learning. Reviewing and planning on the curriculum could be done in a focused manner knowing students strengths and weaknesses in the subject. Remediation and reflection on both teachers and students cannot be done without proper evidence from students' continuous assessment and proper examinations report. To upgrade teachers we need a concerted effort to change their attitude towards better knowledge and effective ways of keeping students' academic portfolios.

\section{REFERENCES}

[1] Buckland, M. (1994). Annual meeting, History of information science: An update and preview. Bulletin of the American Society for Information Science, 20 (6), 6.

[2] Calfee, R. C., \& Perfumo, P. (1993). "Student Portfolios: Opportunities for a Revolution in Assessment." Journal of Reading. 36 (7), 532-538.

[3] Cole, D. J., Ryan, C., \& Kick, F. (2000). Portfolios across the Curriculum and Beyond. California. Corwin Press.

[4] Diamond, B.J., \& Moore, M.A. (1995). Multicultural Literacy. New York. Longman Publishers.

[5] Duke, C. R., \& Sanchez, R. (2000). Assessing writing across the curriculum. Durham, NC: Carolina Academic Press.

[6] Flood, J., \& Lapp, D. (1989). Reporting reading progress: A comparison portfolio for parents. The Reading Teacher. (42), 508514.

[7] Gibbs, R.F. (1989). The present and future medico legal importance of record keeping in anesthesia and intensive care: The case for automation. Journal of Clinical Monitoring and Computing. Vol 5 No: (4), 251-255. Springer Netherlands

[8] Hughes, A. (1989). Testing for Language Teachers. Cambridge. Cambridge University Press.

[9] Jankie, D. (2001). Rethinking Setswana Literacy Practices. Towards incorporating Community - Based and students' experiences in Senior Secondary schools classrooms. (Unpublished PhD Thesis) Madison. University of Madison.

[10] Jones, L., \& Bray, E. (1986). Assessment: From Principles to Action. Hong Kong. Macmillan Educational Ltd.

[11] Mokibelo, E. B. (1999). Teaching of Setswana Language in Botswana: The Communicative Approach. (Unpublished MA Thesis) Essex. University of Essex.

[12] Moya, S., \& O'Malley, J.M (1994). A portfolio assessment model for ESL. The Journal of Educational Issues of Language Minority Students, v13 p. 13-36, Spring 1994. 
[13] O’Malley, J.M., \& Pierce, L.V (1996). Authentic Assessment for English Language Learners: Practical Approaches for Teachers: Massachusetts. Addison - Wesley Publishing Company.

[14] Ramahobo, L. (1999). The National Language: A resource or a Problem? Gaborone. Pula Press.

[15] Republic of Botswana. (1993). Report on the National Commission on Education: Gaborone. Botswana Government Printer.

[16] Republic of Botswana. (1997). Junior Certificate Examination Assessment Procedures - Setswana Examinations Research and testing Division Ministry of Education.

[17] Republic of Botswana. (2000). Junior Certificate Examinations Assessment Procedures-Setswana. Gaborone. Government Printers.

[18] Stahle, D. L., \& Mitchell, J. P. (1993). Portfolio Assessment in College Methods Course. Practicing What We Preach. Journal of Reading. 36, (7), $538-542$.

[19] Sweet, D. (1993). Student Portfolios: Classroom Uses. Consumer Guide; Office of Research, Office of Educational Research and Improvement (OERI) of the U.S. Department of Education

[20] Upward, F. (1998). Structuring the records Continuum, Part Two: Structuration Theory and Record Keeping. Records Continuum Research Group, Monash University.

[21] Valencia, S. (1990). A portfolio approach to classroom reading assessment. The whys, what, and hows. Journal of Reading. (43): $338-340$.

[22] Wolf, A. (1993). From informal to formal assessment. Recognizing the role of the classroom teacher. Journal of Reading. Carlifornia. Purdue University. (36); $518-523$.

Eureka B. Mokibelo is a Senior Lecturer in Communication and Study Skills Unit. Her interest in research is on language education policy and practice, implementing language-in-education policy in linguistically and culturally diverse settings and language teaching and learning. She pays special attention to language education policy with regards to ethnic minority groups. She currently teaches, researches, consults in language education policy and practice in Botswana. Also, she is the author of textbooks in language teaching and learning in Setswana language as well as literature at both junior and senior secondary schools in Botswana. 